\title{
The Decapoda collected by the "Huxley" from the North Side of the Bay of Biscay in August, 1906.
}

By

\author{
Stanley Kemp, B.A.
}

THE collection of Decapoda made by the Huxley during her short cruise on the north side of the Bay of Biscay is an extensive one; it comprises no less than forty-nine species-a number which speaks well for the efficiency of the gear employed.

Although, as might be expected, the majority of the species obtained are well-known members of the N.E. Atlantic fauna, the material presents many points of interest. Five species not hitherto known to extend south of the British Isles were found by the Huxley, and in several cases important additions have been made to our knowledge of the bathymetric range.

A specimen which has been tentatively referred to Periclimenes Korni (Lo Bianco) is of the greatest possible interest, for no deepwater representative of the family Palæmonidæ was hitherto known from the N.E. Atlantic. Unfortunately, the species is represented only by a fragment of a single individual; this is particularly irritating, for the collection, as a whole, is in a remarkably good state of preservation.

No close comparison can be made between the species in the present collection and those found by the Caudan in 1895, for the latter expedition worked considerably to the south of the area investigated by the Huxley; nevertheless, two species, Spongicola Koehleri and Uroptychus Bouvieri, which were first described from material obtained by the Caudan, have again been found. Until now, both these forms were known only from the type specimens.

My thanks are due to Dr. E. J. Allen for the opportunity of examining this interesting collection. 


\title{
DECAPODA NATANTIA.
}

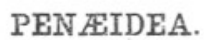

SERGESTID E.

Sergestes arcticus, Kröyer.

\author{
Station VIII. Surface. Many, 9-22 mm.* \\ $\mathrm{X}$. Surface. One, very small. \\ ", XII. 246 fathoms. Five, $29-35 \mathrm{~mm}$.
}

The majority of the specimens only measure from 9 to $15 \mathrm{~mm}$. in length, and the largest $(35 \mathrm{~mm}$.) is not half grown. The examples from St. XII were probably caught in midwater during the ascent of the net.

\section{STENOPIDEA.}

\section{STENOPID}

\section{Spongicola $\uparrow$ Koehleri, Caullery.}

Station XIII. 412 fathoms. Twenty-three, 25-46 mm., and several very young, about $8 \mathrm{~mm}$.

Prior to the date of the Huxley's cruise, this interesting species was known only from five specimens dredged in the Bay of Biscay in 770 fathoms by the Caudan expedition. The additional examples, while in the main confirming the accuracy of Caullery's $\ddagger$ description, show a very considerable amount of variation in the spinulation of the carapace and certain appendages. This variation is indeed so great that no specimen in the collection exhibits precisely the same armature on both sides of its body. The following notes indicate the numbers of spines and spinules observed in some of the more important positions.

The rostrum bears from 6 to 9 teeth on its dorsal aspect. Ventrally there are two ridges (for the rostrum is triangular in section), each of which is furnished with from 0 to 4 spinules. Occasionally the foremost spinule is median in position owing to the confluence of the two ridges near the apex. The rounded antero-inferior angle of the carapace bears from 1 to 4 short spines, and from 1 to 4 are situated on the lateral face of the carapace a little behind the margin. At the

* The measurements of all the Natantia mentioned in this paper were taken from the tip of the rostrum to the apex of the telson.

† Bouvier (Mem. Mus. Comp. Zool., Harvard, XXVII, 3, 1909, p. 264) gives a useful table for the discrimination of the five species comprised in this genus.

‡ "Schizopodes et Décapodes de la Campagne du Caudan." Ann. Univ. Lyon, XXVI, 1895 , p. 382 . 
base of the rostrum on either side there are from 0 to 3 spines, while the posterior margin of the gastric groove may be wholly unarmed or may be provided with as many as twelve spinules. There are from 2 to 5 spinules, often blunt and inconspicuous, on the outer margin of the antennal scale, and from 4 to 14 on either side of the telson. There may also be one or two stout spines on the internal margin of the merus of third pereiopod.

The eyes, as Caullery has observed, are devoid of black pigment, except for an annular band at the proximal edge of the cornea. The small and rudimentary exopod which Spence Bate has figured * at the base of the third maxillipede of Spongicola venusta is not found in S. Koehteri.

The Huxley, like the Caudan, obtained several very young specimens of this species. Those in the present collection measure about $8 \mathrm{~mm}$. in length and evidently represent the earliest free-living stage, for some remain curled up as though still within the eggshell. The rostrum and all the appendages of the cephalothorax are well developed in these specimens, while the eyes are just as deficient in pigmentation as they are in the adult. The pereiopods are fully segmented, and chelæ are present on the first three pairs, those of the third pair being very noticeable owing to their large size. Conspicuous exopods are retained on the first three pairs. The pleopods are well formed, but the uropods are not yet free and the telson is slightly emarginate distally.

An ovigerous female was found to be carrying sixty-two eggs.

As in the case of the type specimens, the examples of S. Koehleri collected by the Huxley were living in the sponge Regadrella phorix; as a rule a single individual was found inside each sponge.

\section{CARIDEA.}

\section{PASIPH EIDE.}

\section{Pasiphaë sivado (Risso).}

Station VIII. Surface. Many, 35-55 mm.

" IX. 240 fathoms. Eight, 59-69 mm.

„ X. Surface. Many, 8-26 mm.

," XII. 246 fathoms. Twenty-nine, 21-40 mm.

, XIII. 412 fathoms. Two, 40 and $58 \mathrm{~mm}$.

Only once previously has this species been recorded from depths exceeding 400 fathoms: by Adensamer, from 54.3 fathoms in the Mediterranean.

* Challenger Report, 1888, Pl. XXIX, Fig. i". 


\section{Pasiphaë princeps, Smith.}

Station XII. 246 fathoms. One, $69 \mathrm{~mm}$.

This solitary individual is specifically identical with a number of specimens found off the west coast of Ireland. These, although differing in certain features from the original description, have been determined as $P$. princeps, Smith, a species closely allied to P. $\operatorname{tarda}$, Kröyer, but extending much further south.

$P$. princeps had not hitherto been found in as little as 246 fathoms.

\section{PANDALID A.}

Pandalus leptocerus, Smith, var. Bonnieri, Caullery.

Station IX. 240 fathoms. Twenty-six, 35-ca.110 mm.

" XII. 246 fathoms. Thirty-three, $25-98 \mathrm{~mm}$.

Pandalus propinquus, G. O. Sars.

Station VII. $\overline{444}$ fathoms. Nineteen, $27-70 \mathrm{~mm}$.

„ IX. 240 fathoms. Eight, $27-34 \mathrm{~mm}$.

" XII. 246 fathoms. Fifteen, 18-35 mm.

" XIII. 412 fathoms. Thirteen, 31-ca. $75 \mathrm{~mm}$.

$P$. propinquus had not previously been recorded as far south as the Bay of Biscay.

Plesionika martia (A. Milne-Edwards).

Station XII. 246 fathoms. Five; one perfect, $90 \mathrm{~mm}$.

(?) „ XIII. 412 fathoms. One, large, in very bad condition.

The large individual from Station XIII cannot be satisfactorily determined. It appears to have been swallowed by a fish and partially digested.

Pandalina brevirostris (Rathke).

Station IX. 240 fathoms. Three, $21-25 \mathrm{~mm}$.

" XII. 246 fathoms. Thirty, 12-25 mm.

Several of the female specimens are ovigerous.

HipPOLYTID A.

Hippolyte varians, Leach.

Station II. 75 fathoms. One, $17 \mathrm{~mm}$. ; an ovigerous female.

Caridion Gordoni (Spence Bate).

Station IX. 240 fathoms. Four, 16-21 mm.

,$\quad$ XII. 246 fathoms. Eight, 14-18.5 mm.

The rostra of these specimens bear from six to nine teeth above and from one to three below. 
C. Gordoni was not previously known to the south of the British Isles, and hitherto had not been trawled in depths exceeding 200 fathoms.

\section{Processid e.}

Processa canaliculata, Leach.

Station II. 75 fathoms. Two, 26 and $30 \mathrm{~mm}$.

, V. 109 fathoms. Seventy-six, 21-50 mm.

Two of the specimens have abnormal eyes. The cornea on one side is well developed and of the usual size, whereas that on the other side is much smaller with, in one case, a curious swelling on the inner face of the stalk. The rostrum of the latter specimen is also unusually short, and is not furnished with its full complement of setæ.

\section{PALEMONID F.}

\section{Periclimenes Korni? Lo Bianco.}

Station XIII. 412 fathoms. Fragment.

The rostrum of this specimen is broken off at the base, and the whole of the abdomen is missing. This is particularly unfortunate, for the specimen is, as far as I am aware, the only deep-water Palæmonid which has been found in the North-East Atlantic. It appears to be most closely allied to the imperfectly described Periclimenes (Anchistia) Korni (Lo Bianco), * found near Capri in about 600 fathoms, but is considerably larger and differs from the Italian author's figure in the lengths of various segments of the pereiopods.

The carapace measures $7 \mathrm{~mm}$. from the back of the orbit to the hinder margin of the carapace; it is therefore probable that the specimen was originally more than twice as long as the types of $P$. Korni, which were only $13-15 \mathrm{~mm}$. in total length.

The rostrum is broken, but four dorsal teeth are present on the anterior third of the carapace behind the orbital notch. The dorsal carina is clear and distinct for three-quarters the length of the carapace, fading away further back. Both hepatic and antennal spines are present. The eyes are deeply pigmented and the cornea is wider than the stalk. The outer antennular flagellum is split into two rami, the inner one (which is also the thicker) being slightly longer than the fused basal part. The lamellar portion of the antennal scale is produced acutely at its inner distal angle, and reaches considerably beyond the stout spine which terminates the straight outer margin.

The first pair of pereiopods reaches beyond the apex of the antennal scale by the whole length of the propodus; the merus and

\footnotetext{
* Lo Bianco. Mitt. Zoo. Stat. Neapel, 1903, p. 250, tav. 7, fig. 13.
} 
carpus are nearly equal in length, each being about one and a half times as long as the chela. The second pair is characterised by the very long but comparatively slender chela, which is twice the length of the merus. The carpus is very short, about one-third the length of the merus, and the dactylus is half the length of the palm. The dactylus is strongly curved and sharply pointed apically; it bears a prominent longitudinal carina on either side and a sharp tooth internally in the middle of its basal third. The fixed finger is carinate along its internal aspect only, and bears, in its basal third, two teeth, between which the dactylar tooth fits when the claw is closed. In the last three pairs of pereiopods the propodus is slightly longer than the merus, the carpus is three-fifths the length of the propodus, and the dactylus is very short, simple, curved, and claw-like.

\section{CRANGONIDA.}

Crangon Allmanni, Kinahan.

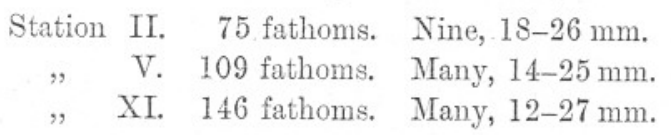

The capture of this species on the north side of the Bay of Biscay in 146 fathoms establishes new records both for its horizontal and bathymetric distribution. C. Allmanni had not hitherto been found south of the British Isles, and was not previously known from depths exceeding 100 fathoms.

The small size of the specimens seems to indicate that the species is unable to attain its maximum development in deep water.

\section{Philocheras* echinulatus, M. Sars.}

Station IX. 240 fathoms. Forty-eight, 14-34 mm.

" XII. 246 fathoms. Many, 14-35 mm.

This species was not previously known as far south as the Bay of Biscay.

Philocheras bispinosus, Hailstone, var. neglectus, G. O. Sars.

Station II. 75 fathoms. Two, $11.5 \mathrm{~mm}$.

These two specimens show no trace of the brown pigment which is sometimes such a prominent feature of the var. neglectus when living. The surface of the carapace and abdomen is, however, without trace of tubercles, and is pitted with microscopic punctuations exactly as in the forms with transverse brown bands. 
P. bispinosus var. neglectus had not hitherto been recorded from as far south as the Bay of Biscay nor from as much as 75 fathoms. The typical form is, however, known to extend to the Azores and has been found off the west coast of Ireland in as much as 200 fathoms.

IEgeon Lacazei (Gourret).

Station IX. 240 fathoms. Fourteen, 19.5-28 mm.

". XII. 246 fathoms. Eight, $20-25 \mathrm{~mm}$.

This scarce species is closely allied to the common Mediterranean form $A$. cataphractus. It was originally described by Gourret from specimens found in the vicinity of Marseilles, and since then twelve examples have been trawled off the west coast of Ireland between 160 and 374 fathoms.

Pontophilus spinosus (Leach).

Station IX. 240 fathoms. Seven, $28-38 \mathrm{~mm}$.

"XII. 246 fathoms. Three, 9-12 mm.

Pontophilus norvegicus, M. Sars.

Station XII. 246 fathoms. Three, 13-17 mm.

\title{
DECAPODA REPTANTIA.
}

\section{ERYONIDEA.}

ERYONIDA.

Polycheles typhlops, Heller.

Station XII. 246 fathoms. Two, $29 \mathrm{~mm}$.

\author{
SCYLIARIDEA. \\ Palinuride. \\ "Phyllosoma" (larva).
}

Station VIII. Surface. Two.

\section{GALATHEIDEA.}

UROPTYCHID A.

Uroptychus rubrovittatus (A. Milne-Edwards).

Station VII. $\overrightarrow{444}$ fathoms. Four, $15-30 \mathrm{~mm}^{*}$

,$\quad$ XII. 412 fathoms. One, $19 \mathrm{~mm}$.

* The measurements of all the Galatheidea mentioned in this paper were taken from the apex of the rostrum to the extremity of the telson, with the abdomen stretched out in macrurous fashion. 


\section{THE DECAPODA COLLECTED BY THE "HUXLEY" FROM THE}

Uroptychus nitidus var. concolor (A. Milne-Edwards). Station XIII. 412 fathoms. One, $30 \mathrm{~mm}$.

\section{Uroptychus Bouvieri, Caullery.}

Station XIII. 412 fathoms. Three, $14 \cdot 5-22 \mathrm{~mm}$.

This is the first time this species has been recorded since it was described by Caullery.* The type specimens, two males, were found by the Caudan expedition between 218 and 273 fathoms.

Two of the examples collected by the Huxley are ovigerous females, and measure 22 and $20.5 \mathrm{~mm}$. from the tip of the rostrum to the apex of the telson; the third is a male, $14.5 \mathrm{~mm}$. in length. The first pereiopods measure 26, 24, and $23.5 \mathrm{~mm}$. respectively, thus showing that this limb is much more strongly developed in the male than in the female.

Little can be added to Caullery's careful description. The small median denticle behind the base of the rostrum is absent in all the specimens, the lateral spines on the carapace vary in number from five to six, and the antennal scale reaches to two-thirds the length of the rostrum, and is narrower at its base than in the figure of the type. The notch in the sternal plaston is, in the female, rectangular in shape, and considerably deeper than in the male.

Only four longitudinal rows of spines can be found on the merus and carpus of the first pereiopod, and the internal edge of the propodus of the same limb is upturned and denticulate proximally and is separated from the smooth dorsal surface by a well-defined groove.

The eggs, which appear to be on the point of hatching, measure about $1.5 \mathrm{~mm}$ in length.

Gastroptychus formosus (A. M.-Edw. and Bouvier).

Station VII. $\dot{444}$ fathoms. One, $18 \mathrm{~mm}$.

, XIII. 412 fathoms. Two, 21 and $38 \mathrm{~mm}$.

One of the specimens from Station XIII is an ovigerous female.

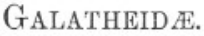

\section{Galathodes tridentatus (Esmark).}

Station VII. $\dot{444}$ fathoms. Twenty-four, $6 \cdot 5-28 \mathrm{~mm}$.

, XIII. 412 fathoms. Four, 18-20 mm.

Nine females are ovigerous.

* "Schizopodes et Décapodes de la Campagne du Caudan," Ann. Univ. Lyon, XXVI, 1895 , p. 394. 
Galathea nexa, Embleton.

Station II. 75 fathoms. Two, 16 and $23 \mathrm{~mm}$.

, V. 109 fathoms. One small; broken.

" XI. 146 fathoms. Six, 10-21 mm.

", XII. 246 fathoms. Two, 15 and $18 \mathrm{~mm}$.

Compared with Bonnier's figures the third maxillipede in these specimens bears a closer resemblance to $G$. dispersa than to $G$. nexce. Recent authors are, however, agreed that these two forms are merely variations of a single species, and although the form known as disperse is far the commoner, yet this name must lapse in favour of nexa, which has priority.*

\section{Munida bamffica (Pennant).}

Station IX. 240 fathoms. Two, 24 and $33 \mathrm{~mm}$.

„ XII. 246 fathoms. Four, $25-33 \mathrm{~mm}$.

, XIII. 412 fathoms. One, $23 \mathrm{~mm}$.

Although the specimens are small, they all present the scaly appearance on the thoracic sternum which so readily separates this species from its close ally Munida tenuimana.*

\section{PAGURIDEA.}

PAGURIDA.

\section{Eupagurus bernhardus (Linn.).}

Station II. 75 fathoms. One, very small.

\section{Eupagurus Prideauxi (Leach).}

Station II. 75 fathoms. Five.

, V. 109 fathoms. Four.

, VI. 87 fathoms. One.

In the largest specimen, which is an ovigerous female from Station VI, the carapace measures $15 \mathrm{~mm}$. in length.

Eupagurus variabilis, A. M.-Edw. and Bouvier.

Station IX. 240 fathoms. Twenty-six.

$\begin{array}{rrll} & \text { XI. } & 146 \text { fathoms. } & \text { Sixteen. } \\ " & \text { XII. } & 246 \text { fathoms. } & \text { Twelve. } \\ " & \text { XIII. } & 412 \text { fathoms. } & \text { One. }\end{array}$

The largest example, taken at Station IX, measures $62 \mathrm{~mm}$. from the hinder margin of the cephalothorax to the distal extremity of the large chela. All the specimens are typical in form with the exception of two, in which the propodus of the right chela is slightly excavate.

\footnotetext{
* v. Hansen, Danish Ingolf Malacostraca, 1908, pp. 31 and 32.
} 
Eupagurus carneus, Pocock.

Station VII. $\dot{444}$ fathoms. One.

"XIII. 412 fathoms. Two.

The largest specimen measures only $28 \mathrm{~mm}$. from the hinder margin of the cephalothorax to the distal extremity of the large chela.

Anapagurus lævis (W. Thompson).

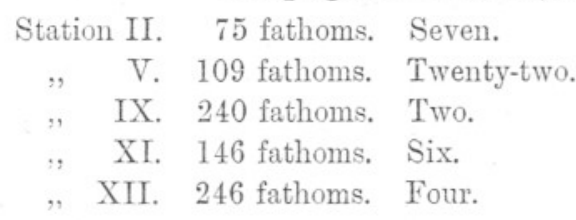

OXYSTOMATA.

DORIPPIDA.

Cymonomus granulatus (Norman).

Station XII. 246 fathoms. One, $4 \mathrm{~mm}$.*

LeUCosinde.

Ebalia tuberosa (Pennant).

Station V. 109 fathoms. One, $12.5 \mathrm{~mm}$.

This species does not seem to have been recorded hitherto from as much as 109 fathoms.

Ebalia tumefacta (Montagu).

Station II. 75 fathoms. One, $7 \mathrm{~mm}$.

, V. 109 fathoms. Two, 8 and $8.5 \mathrm{~mm}$.

Ebalia nux, Norman.

Station V. 109 fathoms. One, $7.5 \mathrm{~mm}$.

, IX. 240 fathoms. Eight, 6.5-8.5 mm.

,. XI. 146 fathoms. Three, $7-7.5 \mathrm{~mm}$.

, XII. 412 fathoms. $7-8 \mathrm{~mm}$.

Several of the specimens are ovigerous females.

BRACHYGNATHA.

Portunide.

Portunus holsatus, Fabricius.

Station II. 75 fathoms. Eighteen, 10.5-18 mm.

" V. 109 fathoms. Three, 6.5-8.5 mm.

- Length of carapace. 
The specimens are all very young, but in my opinion they can be referred with safety to this species. Hitherto $P$. holsatus has not been recorded from depths exceeding 70 fathoms.

\section{Portunus pusillus, Leach.}

Station V. 109 fathoms. Eighteen, 5-9 mm.

It is with some doubt that these small specimens are referred to $P$. pusillus. The median frontal tooth is, in several instances, not more advanced than the lateral, but it is probable that with growth this feature would become more apparent.

\section{Portunus tuberculatus, Roux.}

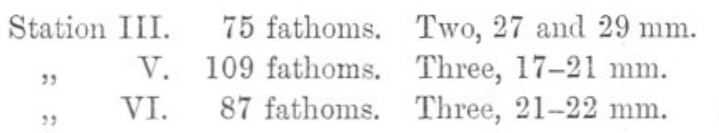

Polybius Henslowi, Leach.

Station II. 75 fathoms. One, $36 \mathrm{~mm}$.

\section{Bathynectes superba (Costa).}

Station VII. $\dot{444}$ fathoms. Two; one $11 \mathrm{~mm}$., one broken.

" IX. 240 fathoms. Seven, about $5.5 \mathrm{~mm}$.

" XII. 246 fathoms. Fifty-three; one large and very macerated, the rest 5-6 mm.

" XIII. 412 fathoms. Four.

In the small specimens the form of the carapace resembles Bouvier's figure * of an individual $4.5 \mathrm{~mm}$. in length; the frontal margin is fourlobed, the second and fourth antero-lateral spines are extremely short, while the fifth is not specially longer than the third. In the two large specimens from Station XIII the hindmost spines of the anterolateral series are very long; they measure 50 and $46 \mathrm{~mm}$. in breadth without these spines, while, including them, they measure 84 and $80 \mathrm{~mm}$.

\section{Geryon sp. ?}

Station XII. 246 fathoms. One, broken, $5 \mathrm{~mm}$.

\section{ATELECYCLID e.}

\section{Atelecyclus septemdentatus (Montagu).}

Station II. 75 fathoms. Two, 15 and $17 \mathrm{~mm}$.

\footnotetext{
* Bouvier, Rés. Camp. Sci. Monaco, XIII, 1899, Pl. II, fig. 1.
} 


\section{MaIID 2.}

Inachus dorsettensis (Pennant).

Station V. 109 fathoms. Four, 13-18 mm.

, VI. 87 fathoms. Two, 19 and $20 \mathrm{~mm}$.

\section{Inachus leptochirus, Leach.}

Station II. 75 fathoms. Sixteen, 12-22 mm.

, VI. 87 fathoms. Five, 18-22 mm.

„ XI. 146 fathoms. Two, 9 and $12.5 \mathrm{~mm}$.

Stenorhynchus longirostris (Fabricius).

Station II. 75 fathoms. Twelve, 10-20 mm.

" V. 109 fathoms. Two, 9.5 and $17.5 \mathrm{~mm}$.

, IX. 240 fathoms. One, $22 \mathrm{~mm}$.

\section{Lispognathus Thomsoni (Norman).}

Station VII. $\dot{444}$ fathoms. One, $7 \mathrm{~mm}$.

„ XIII. 412 fathoms. Four, 4-7 mm.

Ergasticus Clouei, A. Milne-Edwards.

Station V. 109 fathoms. One, $8 \mathrm{~mm}$.

" IX. 240 fathoms. One, $11 \mathrm{~mm}$.

" XII. 246 fathoms. Four, 9-18 mm.

Hyas coarctatus, Leach.

Station VI. 87 fathoms. One, $26 \mathrm{~mm}$. 
LIST OF SPECIES, AND THE STATIONS AT WHICH THEY OCCURRED.

\begin{tabular}{|c|c|c|c|c|c|c|c|c|c|c|c|c|c|c|c|c|c|c|}
\hline & & Statio & on $\mathrm{N}$ & No. & - & . & . & II & III & $\mathrm{v}$ & VI & VII & VIII & IX & $\mathrm{x}$ & $\mathrm{XI}$ & XII & XIII \\
\hline & & $\begin{array}{l}\text { Latitu } \\
\text { Longi }\end{array}$ & $\begin{array}{l}\text { ude, } \\
\text { itude, }\end{array}$ & N. & . & : & : & $\begin{array}{c}4 S^{\circ} 2 t^{\prime} \\
6^{\circ} 2 S^{\prime}\end{array}$ & $\begin{array}{c}48^{\circ} 24^{\prime} \\
6^{\circ} 33^{\prime}\end{array}$ & $\begin{array}{c}47^{\circ} 4 S^{\prime} \\
7^{\circ} 46^{\prime}\end{array}$ & $\begin{array}{c}47^{\circ} 46^{\prime} \\
7^{\circ} 12^{\prime}\end{array}$ & $\begin{array}{c}47^{\circ} 36^{\prime} \\
7^{\circ} 31^{\prime}\end{array}$ & $\begin{array}{l}47^{\circ} 30^{\prime} \\
7^{\circ} 31^{\prime}\end{array}$ & $\begin{array}{l}48^{\circ} 7^{\prime} \\
8^{\circ} 13^{\prime}\end{array}$ & $\begin{array}{l}48^{\circ} 7^{\prime} \\
8^{\circ} 13^{\prime}\end{array}$ & $\begin{array}{c}4 \mathrm{~S}^{\circ} 10^{\prime} \\
\mathrm{S}^{\circ} 11^{\prime}\end{array}$ & $\begin{array}{l}48^{\circ} 7^{\prime} \\
8^{\circ} 13^{\prime}\end{array}$ & $\begin{array}{l}48^{\circ} 7^{\prime} \\
8^{\circ} 13^{\prime}\end{array}$ \\
\hline & & Fathor & & . & . & & . & 75 & 75 & 109 & 87 & $\dot{444}$ & Surface. & 240 & Surface. & 146 & 246 & 412 \\
\hline \multicolumn{19}{|l|}{ Natantia. } \\
\hline Sergestes arcticus & . & . & . & . & & . & . & $\ldots$ & $\ldots$ & $\ldots$ & $\ldots$ & $\ldots$ & many & $\ldots$ & 1 & $\ldots$ & 5 & \\
\hline Spongicola Koehleri & . & . & . & : & & . & . & $\ldots$ & $\ldots$ & $\ldots$ & $\ldots$ & $\ldots$ & $\ldots$ & $\ldots$ & $\ldots$ & $\ldots$ & $\ldots$ & 23 \\
\hline Pasiphaë sivado. & . & . & . & . & & . & . & $\ldots$ & $\ldots$ & $\ldots$ & $\ldots$ & $\ldots$ & many & 8 & many & $\ldots$ & 29 & 2 \\
\hline Pasiphaë princeps & . & i & : & . & & . & . & $\cdots$ & $\ldots$ & $\ldots$ & $\ldots$ & $\ldots$ & $\ldots$ & $\ldots$ & $\ldots$ & $\ldots$ & 1 & \\
\hline Pandalus leptocerus $\mathrm{v}$. & Bol & onnieri & . & . & & . & . & $\ldots$ & $\ldots$ & $\ldots$ & $\ldots$ & $\ldots$ & $\ldots$ & 26 & $\ldots$ & $\ldots$ & 33 & \\
\hline Pandalus propinquus & . & . & . & . & & . & . & $\ldots$ & $\ldots$ & $\ldots$ & $\ldots$ & 19 & $\ldots$ & 8 & $\ldots$ & $\ldots$ & 15 & 13 \\
\hline Plesionika martia & . & . & . & . & & . & . & $\ldots$ & $\ldots$ & $\ldots$ & $\ldots$ & $\ldots$ & $\ldots$ & $\ldots$ & $\ldots$ & $\ldots$ & 5 & $?$ \\
\hline Pandalina brevirostris & . & . & . & . & & . & . & $\ldots$ & $\ldots$ & $\ldots$ & $\ldots$ & $\ldots$ & $\ldots$ & 3 & $\ldots$ & $\ldots$ & 30 & \\
\hline Hippolyte varians & . & . & . & . & & . & . & 1 & & & & & & & & & & \\
\hline Caridion Gordoni & . & . & . & . & & . & . & $\ldots$ & $\ldots$ & $\ldots$ & $\ldots$ & $\ldots$ & $\ldots$ & 4 & $\ldots$ & $\ldots$ & 8 & \\
\hline Processa canaliculata & . & . & . & . & & . & . & 2 & $\ldots$ & 76 & & & & & & & & \\
\hline Periclimenes Korni? & . & . & . & . & & . & . & $\ldots$ & $\ldots$ & $\ldots$ & $\ldots$ & .. & $\ldots$ & $\ldots$ & $\ldots$ & $\ldots$ & $\ldots$ & 1 \\
\hline Crangon Allmanni & . & . & . & . & & . & . & 9 & $\ldots$ & many & $\cdots$ & $\ldots$ & $\ldots$ & $\ldots$ & $\ldots$ & many & $\ldots$ & $\ldots$ \\
\hline Philocheras echinulatu & & $\cdot$ & . & . & & . & . & $\ldots$ & $\ldots$ & $\ldots$ & $\ldots$ & $\ldots$ & $\ldots$ & 48 & $\ldots$ & $\ldots$ & many & . \\
\hline Philocheras bispinosus & s v. 1 & neglect & & . & & . & . & 2 & & & & & & & & & & \\
\hline Ægeon Lacazei . & . & . & . & . & & . & . & $\cdots$ & $\ldots$ & $\ldots$ & $\ldots$ & $\cdots$ & $\ldots$ & 14 & $\ldots$ & $\ldots$ & 8 & \\
\hline Pontophilus spinosus & . & . & . & . & & . & . & $\ldots$ & $\ldots$ & $\ldots$ & $\ldots$ & $\ldots$ & $\ldots$ & 7 & $\ldots$ & $\ldots$ & 3 & \\
\hline Pontophilus norvegicus & & . & . & . & & . & . & $\cdots$ & $\cdots$ & $\cdots$ & $\cdots$ & $\cdots$ & $\cdots$ & $\cdots$ & $\cdots$ & $\cdots$ & 3 & \\
\hline \multicolumn{19}{|l|}{ Reptantia. } \\
\hline Polycheles typhlops & . & . & . & . & & . & . & $\ldots$ & $\cdots$ & $\ldots$ & $\cdots$ & $\cdots$ & $\ldots$ & $\cdots$ & $\cdots$ & $\cdots$ & 2 & \\
\hline 'Phyllosoma' larva & . & . & . & . & & . & . & $\ldots$ & $\ldots$ & $\ldots$ & $\ldots$ & $\ldots$ & 2 & & & & & \\
\hline Uroptychus rubrovitta & atus & & . & . & & . & . & $\ldots$ & $\ldots$ & $\ldots$ & $\ldots$ & 4 & $\ldots$ & $\cdots$ & $\ldots$ & $\cdots$ & $\cdots$ & 1 \\
\hline Uroptychus nitidus $\mathrm{v}$. & con & acolor & . & . & & . & . & $\ldots$ & $\ldots$ & $\ldots$ & $\ldots$ & $\ldots$ & $\ldots$ & $\ldots$ & $\ldots$ & $\ldots$ & $\ldots$ & 1 \\
\hline Uroptychus Bouvieri & . & . & . & . & & . & . & $\ldots$ & $\ldots$ & $\ldots$ & $\ldots$ & $\ldots$ & $\ldots$ & $\ldots$ & $\ldots$ & $\ldots$ & $\ldots$ & 3 \\
\hline Gastroptychus formosu & & . & . & . & & . & . & $\ldots$ & $\ldots$ & $\ldots$ & $\ldots$ & 1 & $\ldots$ & $\ldots$ & $\ldots$ & $\ldots$ & $\ldots$ & 2 \\
\hline
\end{tabular}


LIST OF SPECIES, AND THE STATIONS AT WHICH THEY OCCURRED-continued.

\begin{tabular}{|c|c|c|c|c|c|c|c|c|c|c|c|c|c|c|c|c|c|}
\hline & & TATION & No. & . & . & . & II & III & $\nabla$ & VI & VII & VIII & IX & $\mathrm{x}$ & $\mathrm{XI}$ & XII & XIII \\
\hline & \multicolumn{4}{|c|}{$\begin{array}{l}\text { Latitude, N. } \\
\text { Longitude, w. }\end{array}$} & : & : & $\begin{array}{l}48^{\circ} 24^{\prime} \\
6^{\circ} 28^{\prime}\end{array}$ & $\begin{array}{l}48^{\circ} 2 t^{\prime} \\
6^{\circ} 33^{\prime}\end{array}$ & $\begin{array}{l}47^{\circ} 48^{\prime} \\
7^{\circ} 46^{\prime}\end{array}$ & $\begin{array}{l}47^{\circ} 46^{\prime} \\
7^{\circ} 12^{\prime}\end{array}$ & $\begin{array}{r}47^{\circ} 36^{\prime} \\
7^{\circ} 31^{\prime}\end{array}$ & $\begin{array}{l}47^{\circ} 30^{\prime} \\
7^{\circ} 31^{\prime}\end{array}$ & $\begin{array}{l}48^{\circ} 7^{\prime} \\
S^{0} 13^{\prime}\end{array}$ & $\begin{array}{l}48^{\circ} 7^{\prime} \\
8^{\circ} 13^{\prime}\end{array}$ & $\begin{array}{l}48^{\circ} 10^{\prime} \\
8^{\circ} 11^{\prime}\end{array}$ & $\begin{array}{l}48^{\circ} 7^{\prime} \\
8^{\circ} 13^{\prime}\end{array}$ & $\begin{array}{l}4 S^{\circ} 7^{\prime} \\
8^{\circ} 13^{\prime}\end{array}$ \\
\hline & & Fathoms & $\mathrm{s}$. & . & . & . & 75 & 75 & 109 & 87 & $\overline{444}$ & Surface. & 240 & Surface. & 146 & 240 & 412 \\
\hline Galathodes tridentatus & & . & . & & . & . & $\cdots$ & $\ldots$ & & $\ldots$ & 24 & $\ldots$ & $\ldots$ & $\ldots$ & $\cdots$ & & 4 \\
\hline Galathea nexa . & . & . & . & & . & . & 2 & $\ldots$ & 1 & $\ldots$ & $\ldots$ & $\cdots$ & $\ldots$ & $\ldots$ & 6 & 2 & \\
\hline Munida bamffica . & . & . & . & & . & . & $\ldots$ & $\ldots$ & $\ldots$ & $\ldots$ & $\ldots$ & $\ldots$ & 2 & $\ldots$ & $\ldots$ & 4 & 1 \\
\hline $\begin{array}{l}\text { Eupagurus bernhardus } \\
\text { Eupagurus Prideanxi }\end{array}$ & & . & . & & . & . & 1 & & & & & & & & & & \\
\hline $\begin{array}{l}\text { Eupagurus Prideauxi } \\
\text { Eupacurus yariabilis }\end{array}$ & . & . & . & & . & $\cdot$ & 5 & $\cdots$ & 4 & 1 & & & & & & & \\
\hline Eupagurus variabilis & · & . & . & & . & . & $\cdots$ & $\ldots$ & $\cdots$ & $\ldots$ & $\because$ & $\ldots$ & 26 & $\ldots$ & 16 & 12 & 1 \\
\hline $\begin{array}{l}\text { Eupagurus carneus } \\
\text { Anapagurns laevis }\end{array}$ & . & $\cdot$ & . & & . & $\cdot$ & $\dddot{7}$ & $\cdots$ & $\ldots$ & $\cdots$ & 1 & $\cdots$ & $\ldots$ & $\cdots$ & $\ldots$ & $\ldots$ & 2 \\
\hline & : & . & . & & . & $\cdot$ & 7 & $\cdots$ & 22 & $\ldots$ & $\cdots$ & $\ldots$ & 2 & $\cdots$ & 6 & 4 & \\
\hline $\begin{array}{l}\text { Cymonomus granulatu } \\
\text { Ebalia tuberosa. }\end{array}$ & s & : & · & & · & $\cdot$ & $\cdots$ & $\cdots$ & $\dddot{j}$ & $\cdots$ & $\cdots$ & $\cdots$ & $\cdots$ & $\cdots$ & $\cdots$ & 1 & \\
\hline $\begin{array}{l}\text { Ebalia tuberosa } \\
\text { Ebalia tumefacta. }\end{array}$ & : & ; & : & & : & $\cdot$ & $\dddot{1}$ & $\begin{array}{l}\ldots \\
\ldots\end{array}$ & $\begin{array}{l}1 \\
2\end{array}$ & & & & & & & & \\
\hline $\begin{array}{l}\text { Ebalia tumefacta. } \\
\text { Ebalia nux . }\end{array}$ & . & . & : & & $\dot{.}$ & $\dot{.}$ & $\ldots$ & $\ldots$ & 1 & $\ldots$ & $\ldots$ & $\ldots$ & 8 & $\ldots$ & 3 & 3 & \\
\hline Portunus holsatus & . & . & . & & & . & 18 & $\ldots$ & 3 & & $\cdots$ & $\cdots$ & & $\cdots$ & & & \\
\hline Portunus pusillus & . & . & . & & . & . & $\ldots$ & $\ldots$ & 18 & & & & & & & & \\
\hline Portunus tuberculatus & & . & . & & . & . & $\ldots$ & 2 & 3 & 3 & & & & & & & \\
\hline Polybius Henslowi & . & . & . & & . & . & 1 & & & & & & & & & & \\
\hline Bathynectes superba & . & . & . & & . & $\cdot$ & $\cdots$ & $\cdots$ & $\cdots$ & $\cdots$ & 2 & $\cdots$ & 7 & $\cdots$ & $\cdots$ & 53 & 4 \\
\hline $\begin{array}{l}\text { Geryon sp. } \\
\text { Atelecyclus septemdent }\end{array}$ & & is. & : & & · & $\therefore$ & $\dddot{2}$ & $\cdots$ & $\cdots$ & $\cdots$ & $\cdots$ & $\cdots$ & $\cdots$ & $\cdots$ & $\cdots$ & 1 & \\
\hline Inachus dorsettensis & . & . & . & & . & . & $\ldots$ & $\ldots$ & 4 & 2 & & & & & & & \\
\hline Inachus leptochirus. & . & . & . & & . & . & 16 & $\ldots$ & $\ldots$ & 5 & & $\ldots$ & $\cdots$ & $\ldots$ & 2 & & \\
\hline Stenorhynchus longiro & stris & s. & . & & . & . & 12 & $\ldots$ & 2 & $\ldots$ & . & $\ldots$ & 1 & & & & \\
\hline Lispognathus Thomson & & . & . & & . & & & & $\ldots$ & $\ldots$ & 1 & $\cdots$ & $\because$. & & $\ldots$ & & 4 \\
\hline Ergasticus Clouei & . & . & . & & & . & $\ldots$ & $\ldots$ & 1 & $\ldots$ & $\ldots$ & $\cdots$ & 1 & $\ldots$ & $\ldots$ & 4 & \\
\hline Hyas coarctatus . & & . & . & & . & . & & & & 1 & & & & & & & \\
\hline
\end{tabular}

